\title{
Phytochemical and growth responses of Mentha piperita to foliar application of biostimulants under greenhouse and field conditions
}

\author{
MEISAM POURHADI ${ }^{1}$, HASSANALI NAGHDI BADI ${ }^{2 *}$, ALI MEHRAFARIN ${ }^{2}$, HESHMAT OMIDI ${ }^{3}$, \\ REZA HAJIAGHAEE ${ }^{2}$
}

${ }^{1}$ Department of Horticulture Science and Research Branch Islamic Azad University

Tehran, Iran

${ }^{2}$ Medicinal Plants Research Center Institute of Medicinal Plants, ACECR

Karaj, Iran

${ }^{3}$ Agricultural College and Medicinal Plants Research Centre Shahad University

Tehran, Iran

* corresponding author: phone: +98 26 347640109, fax: +98 26 34764021, e-mail: naghdibadi@yahoo.com; h.naghdi@ imp.ac.ir

\section{Summary}

Introduction: The biostimulant products are able to improve quality and quantity of medicinal plants.

Objectives: The comparative effects of biostimulants foliar spraying on peppermint (Mentha piperita L.) were investigated.

Methods: These studies were done on the basis of randomized complete blocks design in 3 replicates during 2015.

Results: In field conditions, the highest leaves and stems dry weight by $400 \mathrm{mg} / \mathrm{l}$ chitosan $(\mathrm{CH})+400$ $\mathrm{mg} / \mathrm{l}$ citric acid (CA), essential oil content by $200 \mathrm{mg} / \mathrm{l}$ chitosan $+400 \mathrm{mg} / \mathrm{l}$ humic acid (HA) + $400 \mathrm{mg} / \mathrm{l}$ citric acid and menthol content in $200 \mathrm{mg} / \mathrm{l}$ chitosan $+800 \mathrm{mg} / \mathrm{l} \mathrm{humic} \mathrm{acid}+400 \mathrm{mg} / \mathrm{l}$ citric acid were observed. In greenhouse conditions, the best results of those mentioned parameters were obtained by 400 $\mathrm{mg} / \mathrm{l}$ chitosan $+800 \mathrm{mg} / \mathrm{l}$ humic acid $+400 \mathrm{mg} / \mathrm{l}$ citric acid, $800 \mathrm{mg} / \mathrm{l}$ humic acid and $400 \mathrm{mg} / \mathrm{l}$ chitosan $+400 \mathrm{mg} / \mathrm{l}$ humic acid $+400 \mathrm{mg} / \mathrm{l}$ citric acid, respectively. 
Conclusions: The foliar application of effective biostimulants could improve the yield quality and quantity of Mentha piperita.

Key words: Mentha piperita L., chitosan, citric acid, humic acid, essential oil, menthol

\section{INTRODUCTION}

Peppermint (Mentha piperita L.) from Lamiaceae family is a cultivated natural hybrid plant of Mentha aquatica L. (water mint) and Mentha spicata L. (spearmint). Its leaves are elliptic, jagged, cross, sharp, and slightly covered with fluff, and its height and width are about $4-7 \mathrm{~cm}$ and $2-3 \mathrm{~cm}$, respectively [1-3]. This plant is cultivated widespread in all regions of the world. It is found wild occasionally with its parent species [4]. Its cultivation is of economic importance due to its essential oil content and menthol as the main ingredient in essential oil, used in oral hygiene products, pharmaceuticals, cosmetics, and food industry. Due to wide antifungal and antibacterial activities of essential oil in peppermint, it became one of the most demanded substances by the perfume and essences industries [5]. Various products of the aerial parts of Mentha species have been used for centuries as tonics, antispasmodic, anti-inflammatory agents, etc. in traditional medicine [6]. Because of these and other factors, essential oil of peppermint ranks high in the market [7].

A mixture of two or more PGRs (Plant Growth Regulators) or the combination with other substances (amino acids, nutrients, vitamins) is known as plant biostimulant, which improves the plant growth in small quantities application [8].

Chitosan is an abundant natural polysaccharide with low toxicity that is environmentally friendly and biodegradable. It is applied in different ways in horticulture and agriculture. Chitosan is obtained by deacetylation of chitin by the enzymatic method or alkaline hydrolysis. In agribusiness, chitosan has been utilized as a bioprotectant and biostimulant in the formulation of seed, fruit and vegetable coating. Chitosan is used to increase the plant productivity [9], control the release of agrochemicals, protect the plants against microorganisms and oxidative stress [10], and stimulates the plant growth [11-12]. In last investigations, an affirmative impact of chitosan has been seen on the growth and development of roots, shoots, and leaves of several plant species. Comparative outcomes were specified within radish (Raphanus raphanistrum L.) and sweet pepper (Capsicum annuum L.) [12-13]. Also, foliar application of chitosan increases vegetative growth and improves fruit quality of cucumber (Cucumis sativus L.) [11]. For other cultivated plants, Bittelli et al. [14] reported that foliar application of chitosan decreased transpiration in pepper plants, and reduced water use by $26-43 \%$ while maintaining biomass production and yield. Bittelli et al. [14] reported that foliar application of chitosan on the cultivated pepper (Capsicum sp.), decreased plant transpiration, and reduced water use by $26-43 \%$ maintaining biomass production and yield. Abdel-Mawgoud et al. [15] research on strawberry (Fragaria ananassa L.) demonstrated that foliar application of chitosan enhanced plant height, number of leaves, fresh and dry weights of the leaves, and yield components.

Humic materials are final products of microbial and chemical decomposition of dead biota in soils and are raised to be the most abundant naturally occurring organic substances on earth and the main components of soil organic matter [16].

Citric acid (2-hydroxy 2,3-propanetricarboxylic acid) is one of the most important organic acids produced by fermentation. Citric acid is a tricarboxylic acid and an intermediate product of plant and animal metabolism. It is a commodity chemical product consumed around the world [17], and the essential constituent in all living beings. It directly plays a role in the production of energy through tricarboxylic acid cycle, as well as in some processes related to the metabolism of carbohydrates, certain amino acids, and fatty acids [18].

The purpose of the study was to investigate the influence of biostimulants including chitosan, humic acid and citric acid on dry mass of raw materials and essential oil total content and composition of peppermint (M. piperita L.) cultivated in greenhouse and filed conditions.

\section{MATERIAL AND METHODS}

In order to evaluate the effects of biostimulants on the growth and phytochemical parameters of Mentha piperita L., field and greenhouse experiments were carried out in 2015 at research field and greenhouse of Medicinal Plants Institute, ACECR $\left(56^{\circ} 35^{\prime} \mathrm{N}\right.$ and $50^{\circ} 58^{\prime} \mathrm{E} ; 1500 \mathrm{~m}$ of elevation). The soil was loam-silt with $0.071 \%$ nitrogen, $48.9 \mathrm{mg} / \mathrm{kg}$ phosphorous, $33.6 \mathrm{mg} / \mathrm{kg}$ potassium, EC $2.71 \mathrm{dS} / \mathrm{m}$, and $\mathrm{pH}$ 8.3. The transplants were supplied by research greenhouse of the Medicinal Plants Institute, 
ACECR. A voucher specimen (4580-MPIH) has been deposited in the Herbarium of Medicinal Plants Institute, ACECR. In greenhouse and field, the study was conducted on the basis of randomized complete blocks design with 10 treatments as described in table 1 for bio-stimulants with 3 replications. In the classic greenhouse, the duration of light and dark for growth was $16 / 8 \mathrm{~h}$. The average day and night temperatures during experiment were $22 \pm 3^{\circ} \mathrm{C}$ and $15 \pm 3^{\circ} \mathrm{C}$, respectively. Also the average relative humidity was $55 \pm 5 \%$. In each pot, five transplants of the same size were cultivated and all treatments were sprayed three times in three months after the establishment. Other crop operations were completed regularly during the growing season as needed (tab. 2). The average day/night temperatures and

\section{Table 1.}

Treatments of bio-stimulants formulations on Mentha piperita L.

\begin{tabular}{ll}
\hline $1-$ & Control treatment (distilled water) \\
\hline $2-$ & $400 \mathrm{mg} / \mathrm{l} \mathrm{CA}$ \\
\hline $3-$ & $400 \mathrm{mg} / \mathrm{l} \mathrm{HA}$ \\
\hline $4-$ & $800 \mathrm{mg} / \mathrm{l} \mathrm{HA}$ \\
\hline $5-$ & $200 \mathrm{mg} / \mathrm{l} \mathrm{CH}+400 \mathrm{mg} / \mathrm{l} \mathrm{CA}$ \\
\hline $6-$ & $400 \mathrm{mg} / \mathrm{l} \mathrm{CH}+400 \mathrm{mg} / \mathrm{l} \mathrm{CA}$ \\
\hline $7-$ & $200 \mathrm{mg} / \mathrm{l} \mathrm{CH}+400 \mathrm{mg} / \mathrm{l} \mathrm{HA}+400 \mathrm{mg} / \mathrm{l} \mathrm{CA}$ \\
\hline $8-$ & $200 \mathrm{mg} / \mathrm{l} \mathrm{CH}+800 \mathrm{mg} / \mathrm{l} \mathrm{HA}+400 \mathrm{mg} / \mathrm{l} \mathrm{CA}$ \\
\hline $9-$ & $400 \mathrm{mg} / \mathrm{l} \mathrm{CH}+400 \mathrm{mg} / \mathrm{l} \mathrm{HA}+400 \mathrm{mg} / \mathrm{l} \mathrm{CA}$ \\
\hline $10-$ & $400 \mathrm{mg} / \mathrm{l} \mathrm{CH}+800 \mathrm{mg} / \mathrm{l} \mathrm{HA}+400 \mathrm{mg} / \mathrm{l} \mathrm{CA}$ \\
\hline
\end{tabular}

CH: chitosan [Poly-(D)glucosamine], Poly[(1,4)-N-acetyl-D-glucose2-amine)]; HA: humic acid $\left[\left(\mathrm{C}_{8} \mathrm{H}_{13} \mathrm{NO}_{5}\right) \mathrm{n}, \mathrm{C}_{187} \mathrm{H}_{186} \mathrm{O}_{89} \mathrm{~N}_{9} \mathrm{~S}_{1}\right]$; CA: citric acid $\left(\mathrm{C}_{6} \mathrm{H}_{8} \mathrm{O}_{7}\right)$ average relative humidity in field conditions are shown in table 3. In the field experiment the treatments were the same as bio-stimulants formulations mentioned in table 1 . Soil samples were derived for analysis before field preparation and were fertilized on the basis of a soil experiment recommendation.

The transplants were transferred in rows $50 \mathrm{~cm}$ apart with the inter-row spacing of $20 \mathrm{~cm}$. Each experimental plot contained of 5 rows. The replicates (blocks) with distance of $1.5 \mathrm{~m}$ one from another and plots with distance of $1 \mathrm{~m}$ from each side were considered. The irrigation and other field practices had been performed as needed (tab. 2). The studied traits per plant were leaves dry weight (g), stems dry weight $(\mathrm{g})$, shoot dry weight $(\mathrm{g})$, and content of essential oil (\% w/v), menthol, menthone, $\alpha$-terpinene, pulegone, menthyl acetate, and menthofuran ( $\mathrm{v} / \mathrm{v} \%)$ per essential oil.

The plant materials were dried in the laboratory at a room temperature $\left(26 \pm 2^{\circ} \mathrm{C}\right)$ away from sunlight to prevent changes in the nature of the plants' constituents until the constant weight was gained. The $50 \mathrm{~g}$ of dried shoots were used for essential oils extraction by hydro distillation method for $4 \mathrm{~h}$ using Clevenger-type apparatus [19]. The oils were dried over anhydrous sodium sulphate and kept at $4^{\circ} \mathrm{C}$ until analyzed.

The GC analysis was carried out on a Younglin Instrument Acme $6000 \mathrm{M}$ gas chromatograph equipped with Flame Ionization Detector (FID) and a HP- 5 capillary column $(30 \mathrm{~m} \times 0.25 \mathrm{~mm} ; 0.25 \mu \mathrm{m}$ film thicknesses). The oven temperature was held at $50^{\circ} \mathrm{C}$ for 5 minutes, and then programmed at $3^{\circ} \mathrm{C}$

Table 2

Planting, spraying and harvesting intervals of peppermint in field and greenhouse

\begin{tabular}{|c|c|c|}
\hline & Operation & Date \\
\hline 1 & Cultivation of transplants in greenhouse/field & 13 April 2015 \\
\hline 2 & Foliar application of bio-stimulants (stage 1) & 10 May 2015 \\
\hline 3 & Foliar application of bio-stimulants (stage 2) & 07 June 2015 \\
\hline 4 & Foliar application of bio-stimulants (stage 3) & 21 July 2015 \\
\hline 5 & Harvest time & 06 August 2015 \\
\hline
\end{tabular}

Table 3.

Monthly temperature and minimum average humidity in 2015

\begin{tabular}{lcccc}
\hline \multirow{2}{*}{ Month } & \multicolumn{3}{c}{ Average temperature $\left[{ }^{\circ} \mathrm{C}\right]$} & Minimum average humidity [\%] \\
\cline { 2 - 4 } & Minimum & Mean & Maximum & 48 \\
\hline April & 6.3 & 12.8 & 19.3 & 43 \\
\hline May & 12.7 & 20 & 27.3 & 34 \\
\hline June & 15.9 & 23.7 & 31.5 & 35 \\
\hline July & 18.1 & 25.8 & 33.6 & 34 \\
\hline August & 19.5 & 27 & 34.5 & 34 \\
\hline
\end{tabular}


per min to $240^{\circ} \mathrm{C}$ and after that programmed at $15^{\circ} \mathrm{C}$ per min to $300^{\circ} \mathrm{C}$ (held for 3 minutes). Other operating conditions were: carrier gas, $\mathrm{He}$ with a flow rate of $0.8 \mathrm{ml} / \mathrm{min}$; injector and detector temperatures was $290^{\circ} \mathrm{C}$, and split ratio, 1:10. GC/MS analysis was performed on a above mentioned GC coupled with an Agilent Technologies 5973 mass system. The other operating conditions were the same conditions as described above, mass spectra were taken at $70 \mathrm{eV}$. Mass range was from $\mathrm{m} / \mathrm{z}$ 35-375 amu. Quantitative data were obtained from the electronic integration of the FID peak areas. The components of the essential oils were identified by comparison of their mass spectra and retention indices with those published in the literature [20-21] and presented in the MS computer library.

Analysis of variance (ANOVA) of the results was done using the SPSS software (ver. 24). The means in the results were compared by Duncan's multiple range test at $p \leq 0.01$.

Ethical approval: The conducted research is not related to either human or animal use.

\section{RESULTS AND DISCUSSION}

\section{Greenhouse experiment}

According to the results of variance analysis in greenhouse experiment, the effect of biostimulants was significant on stems dry weight, aerial parts dry weight, content of menthol, menthone, $\alpha$-terpinene, pulegone, menthyl acetate, and menthofuran $(p \leq 0.01)$, and also on leaves dry weight $(p \leq 0.05)$ (tab. 4 and 5).

\section{Growth traits}

Based on the obtained results of mean comparisons, the highest amount of leaves dry weight was observed in treatment of $400 \mathrm{mg} / \mathrm{l} \mathrm{CH}+800 \mathrm{mg} / \mathrm{l} \mathrm{HA}+400 \mathrm{mg} / \mathrm{l}$ $\mathrm{CA}$, while the lowest was attained in plants treated by $400 \mathrm{mg} / \mathrm{l} \mathrm{CA}$. The highest and the lowest stem dry weight was observed in $400 \mathrm{mg} / \mathrm{l} \mathrm{CH}+800 \mathrm{mg} / \mathrm{l} \mathrm{HA}+$ $400 \mathrm{mg} / \mathrm{l} \mathrm{CA}$ treatment and $400 \mathrm{mg} / \mathrm{l} \mathrm{CA}$, respectively. The highest shoot dry weight was related to treatment with $400 \mathrm{mg} / \mathrm{l} \mathrm{CH}+800 \mathrm{mg} / \mathrm{l} \mathrm{HA}+400 \mathrm{mg} / \mathrm{l} \mathrm{CA}$, however the lowest amount was attained in $400 \mathrm{mg} / \mathrm{l}$ CA (tab. 6).

\section{Phytochemical traits}

Regarding to mean comparison of phytochemical parameters, the highest and lowest amount of essential oil content was observed in $800 \mathrm{mg} / \mathrm{l} \mathrm{HA}$ and $200 \mathrm{mg} / \mathrm{l} \mathrm{CH}+400 \mathrm{mg} / \mathrm{l} \mathrm{CA}$, respectively. The menthol content reached the highest value by treatment of $400 \mathrm{mg} / \mathrm{l} \mathrm{CH}+400 \mathrm{mg} / \mathrm{l} \mathrm{HA}+400 \mathrm{mg} / \mathrm{l} \mathrm{CA}$. The treatment with $400 \mathrm{mg} / \mathrm{l} \mathrm{CA}$ showed the highest amount of menthone and menthofuran component.

Table 4

Analysis of variance for effects of biostimulants formulations on growth parameters in greenhouse condition

\begin{tabular}{lllll}
\hline \multirow{2}{*}{ S.O.V } & df & \multicolumn{3}{c}{ Mean square } \\
\cline { 3 - 5 } & & Leaves dry weight & Stems dry weight & Shoot dry weight \\
\hline Rep.(block) & 2 & 0.0089 & 0.0116 & 0.0381 \\
\hline Treatment & 9 & $0.1016^{*}$ & $0.0903^{* *}$ & $0.353^{* *}$ \\
\hline Error & 18 & 0.0343 & 0.127 & 0.077 \\
\hline CV $(\%)$ & & 14.62 & 15.52 & 11.49 \\
\hline * $^{* *}-$ ns shows significant in $5 \%, 1 \%$, and insignificant, respectively & &
\end{tabular}

Table 5

Analysis of variance for effects of biostimulants formulations on phytochemical parameters in greenhouse conditions

\begin{tabular}{lccccccccc}
\hline \multirow{2}{*}{ S.O.V } & \multirow{2}{*}{ df } & \multicolumn{7}{c}{ Mean square } \\
\cline { 3 - 11 } & & Essential oil content [\%] & Menthol & Menthone & $\alpha$-Terpinene & Pulegone & Menthyl acetate & Menthofuran \\
\hline Rep.(block) & 2 & 0.0048 & 0.827 & 0.172 & 2.520 & 20.026 & 0.335 & 2.516 \\
\hline Treatment & 9 & $0.217^{* *}$ & $77.28^{* *}$ & $18.24^{* *}$ & $8.683^{* *}$ & $2.477^{* *}$ & $1.237^{* *}$ & $5.750^{* *}$ \\
\hline Error & 18 & 0.0045 & 11.75 & 1.51 & 1.503 & 0.511 & 0.178 & 1.575 \\
\hline CV (\%) & & 11.55 & 8.69 & 6.40 & 16.24 & 16.63 & 15.92 & 10.28 \\
\hline
\end{tabular}

${ }^{*, * *}-\mathrm{ns}$ shows significant in $5 \%, 1 \%$, and insignificant, respectively 
The content of $\alpha$-terpinene reached the highest level by foliar application of $400 \mathrm{mg} / \mathrm{l} \mathrm{CH}+800 \mathrm{mg} / \mathrm{l} \mathrm{HA}$ $+400 \mathrm{mg} / \mathrm{l} \mathrm{CA}$. The maximum content of menthyl acetate was related to control treatment. The highest level of pulegone was recorded in $800 \mathrm{mg} / \mathrm{l} \mathrm{HA}$ treatment (tab. 7).

\section{Field experiment}

Considering the variance analysis results in the field experiment, the biostimulants application had significant effect on leaves dry weight, essential oil component of menthyl acetate $(p \leq 0.05)$, and also on content of menthol, menthone, $\alpha$-terpinene, pulegone, menthofuran, stems dry weight and shoot dry weight ( $p \leq 0.01)$ (tab. 8 and 9).

\section{Growth traits}

The highest amount of leaves dry weight was obtained by application of $400 \mathrm{mg} / \mathrm{l} \mathrm{CH}+400 \mathrm{mg} / \mathrm{l} \mathrm{CA}$, while the lowest amount was observed in control treatment. The highest amount of stem dry weight was obtained in $400 \mathrm{mg} / \mathrm{l} \mathrm{CH}+400 \mathrm{mg} / \mathrm{l} \mathrm{CA}$ and the lowest amount in control treatment. Shoot dry weight reached to the highest level by application of $400 \mathrm{mg} / \mathrm{l} \mathrm{CH}+400 \mathrm{mg} / \mathrm{l} \mathrm{CA}$, while the lowest level was obtained in control treatment (tab. 10).

\section{Phytochemical traits}

According to mean comparisons, the highest content of essential oil was related to both treatments of $400 \mathrm{mg} / \mathrm{l} \mathrm{CH}+400 \mathrm{mg} / \mathrm{l} \mathrm{CA}$ and $200 \mathrm{mg} / \mathrm{l} \mathrm{CH}+$ $400 \mathrm{mg} / \mathrm{l} \mathrm{HA}+400 \mathrm{mg} / \mathrm{l} \mathrm{CA}$. The highest menthol content was observed in treatment of $200 \mathrm{mg} / \mathrm{l} \mathrm{CH}+$ $800 \mathrm{mg} / \mathrm{l} \mathrm{HA}+400 \mathrm{mg} / \mathrm{l} \mathrm{CA}$. The maximum amount of menthone and pulegon were recorded in $400 \mathrm{mg} / \mathrm{l}$ $\mathrm{CH}+800 \mathrm{mg} / \mathrm{l} \mathrm{HA}+400 \mathrm{mg} / \mathrm{l} \mathrm{CA}$ treatment. The maximum amount of menthafuran was obtained in foliar application of $400 \mathrm{mg} / \mathrm{l} \mathrm{CH}+400 \mathrm{mg} / \mathrm{l}$ $\mathrm{HA}+400 \mathrm{mg} / \mathrm{l} \mathrm{CA}$, while the highest amount of a-terpinene was recorded in treatment of $400 \mathrm{mg} / \mathrm{l}$ $\mathrm{CH}+800 \mathrm{mg} / \mathrm{l} \mathrm{HA}+400 \mathrm{mg} / \mathrm{l} \mathrm{CA}$. The plants treated with $800 \mathrm{mg} / \mathrm{l} \mathrm{HA}$ showed the maximum value of menthyl acetate (tab. 11).

\section{DISCUSSION}

According to the obtained results, the application of biostimulants formulations had positive effects on growth and phytochemical parameters of $M$. piperita L. plants in greenhouse and field. In the field, the highest leaves dry weight was attained by $400 \mathrm{mg} / \mathrm{l} \mathrm{CH}+400 \mathrm{mg} / \mathrm{l} \mathrm{CA}$ treatment in comparison with control, while in the greenhouse, the treatment of $400 \mathrm{mg} / \mathrm{l} \mathrm{CH}+800 \mathrm{mg} / \mathrm{l} \mathrm{HA}+400 \mathrm{mg} / \mathrm{l}$ $\mathrm{CA}$ increased the leaves dry weight significantly,

Table 6

Mean comparisons for the effects of biostimulants formulations on growth parameters in greenhouse conditions

\begin{tabular}{|c|c|c|c|}
\hline Treatment $^{*}$ & Leaves dry weight per plant $[\mathrm{g}]$ & Stems dry weight per plant $[\mathrm{g}]$ & Shoot dry weight per plant $[\mathrm{g}]$ \\
\hline 1 & $1.04 \pm 0.18$ & $0.97 \pm 0.08$ & $2.01 \pm 0.26$ \\
\hline 2 & $1.04 \pm 0.20$ & $0.91 \pm 0.25$ & $1.95 \pm 0.42$ \\
\hline 3 & $1.15 \pm 0.10$ & $1.09 \pm 0.06$ & $2.24 \pm 0.14$ \\
\hline 4 & $1.10 \pm 0.15$ & $1.15 \pm 0.25$ & $2.26 \pm 0.38$ \\
\hline 5 & $1.31 \pm 0.30$ & $1.32 \pm 0.19$ & $2.63 \pm 0.47$ \\
\hline 6 & $1.35 \pm 0.06$ & $1.26 \pm 0.05$ & $2.62 \pm 0.01$ \\
\hline 7 & $1.34 \pm 0.07$ & $1.17 \pm 0.08$ & $2.51 \pm 0.05$ \\
\hline 8 & $1.39 \pm 0.13$ & $1.24 \pm 0.16$ & $2.63 \pm 0.06$ \\
\hline 9 & $1.29 \pm 0.15$ & $0.98 \pm 0.20$ & $2.28 \pm 0.05$ \\
\hline 10 & $1.63 \pm 0.26$ & $1.47 \pm 0.26$ & $3.10 \pm 0.28$ \\
\hline
\end{tabular}

${ }^{*} 1$ : Control treatment (distilled water),

2: $400 \mathrm{mg} / \mathrm{l} \mathrm{CA}$

3: $400 \mathrm{mg} / \mathrm{l} \mathrm{HA}$

4: $800 \mathrm{mg} / \mathrm{l} \mathrm{HA}$

5: $200 \mathrm{mg} / \mathrm{l} \mathrm{CH}+400 \mathrm{mg} / \mathrm{l} \mathrm{CA}$

6: $400 \mathrm{mg} / \mathrm{l} \mathrm{CH}+400 \mathrm{mg} / \mathrm{l} \mathrm{CA}$

7: $200 \mathrm{mg} / \mathrm{l} \mathrm{CH}+400 \mathrm{mg} / \mathrm{l} \mathrm{HA}+400 \mathrm{mg} / \mathrm{l} \mathrm{CA}$

8: $200 \mathrm{mg} / \mathrm{l} \mathrm{CH}+800 \mathrm{mg} / \mathrm{l} \mathrm{HA}+400 \mathrm{mg} / \mathrm{l} \mathrm{CA}$

9: $400 \mathrm{mg} / \mathrm{l} \mathrm{CH}+400 \mathrm{mg} / \mathrm{l} \mathrm{HA}+400 \mathrm{mg} / \mathrm{l} \mathrm{CA}$

10: $400 \mathrm{mg} / \mathrm{l} \mathrm{CH}+800 \mathrm{mg} / \mathrm{l} \mathrm{HA}+400 \mathrm{mg} / \mathrm{l} \mathrm{CA}$ 
Table 7

Mean comparisons for the effects of biostimulants formulations on phytochemical parameters in greenhouse condition

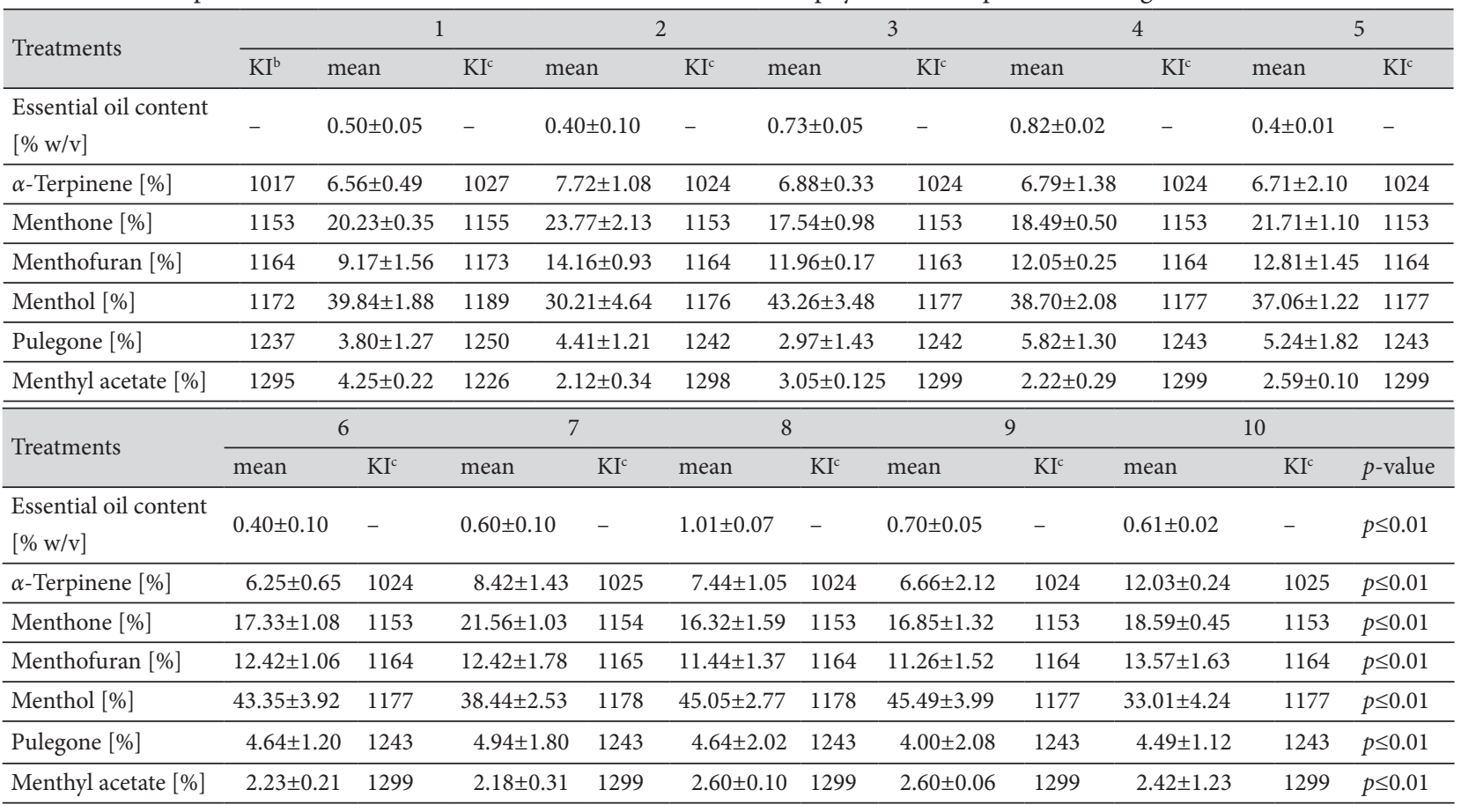

a 1 Control treatment (distilled water)

2: $400 \mathrm{mg} / \mathrm{l} \mathrm{CA}$

3: $400 \mathrm{mg} / \mathrm{l} \mathrm{HA}$

4: $800 \mathrm{mg} / \mathrm{l} \mathrm{HA}$

5: $200 \mathrm{mg} / \mathrm{l} \mathrm{CH}+400 \mathrm{mg} / \mathrm{l} \mathrm{CA}$

6: $400 \mathrm{mg} / \mathrm{l} \mathrm{CH}+400 \mathrm{mg} / \mathrm{l} \mathrm{CA}$

7: $200 \mathrm{mg} / \mathrm{l} \mathrm{CH}+400 \mathrm{mg} / \mathrm{l} \mathrm{HA}+400 \mathrm{mg} / \mathrm{l} \mathrm{CA}$

8: $200 \mathrm{mg} / \mathrm{l} \mathrm{CH}+800 \mathrm{mg} / \mathrm{l} \mathrm{HA}+400 \mathrm{mg} / \mathrm{l} \mathrm{CA}$

9: $400 \mathrm{mg} / \mathrm{l} \mathrm{CH}+400 \mathrm{mg} / \mathrm{l} \mathrm{HA}+400 \mathrm{mg} / \mathrm{l} \mathrm{CA}$

10: $400 \mathrm{mg} / \mathrm{l} \mathrm{CH}+800 \mathrm{mg} / \mathrm{l} \mathrm{HA}+400 \mathrm{mg} / \mathrm{l} \mathrm{CA}$

b: Kovats index in reference [18];

c: Calculated Kovats index relative to $\mathrm{C}_{8}-\mathrm{C}_{24} \mathrm{n}$-alkanes on the HP-5 column.

\section{Table 8}

Analysis of variance for effects of biostimulants formulations on growth parameters in field conditions

\begin{tabular}{lcccc} 
& & & & Mean square \\
\cline { 3 - 5 } & & S.O.V & & Stems dry weight \\
\hline Rep.(block) & 2 & 0.2809 & 2.486 & $17.709^{* *}$ \\
\hline Treatment & 9 & $2.428^{*}$ & 1.882 & $31.704^{* *}$ \\
\hline Error & 18 & 0.801 & 3.601 \\
\hline CV $(\%)$ & & 22.39 & 19.43 \\
\hline
\end{tabular}

${ }^{*, * *}$ - ns shows significant in $5 \%, 1 \%$, and insignificant, respectively

Table 9

Analysis of variance for effects of biostimulants formulations on phytochemical parameters in field conditions

\begin{tabular}{|c|c|c|c|c|c|c|c|c|}
\hline \multirow{2}{*}{ S.O.V } & \multirow{2}{*}{$\mathrm{df}$} & \multicolumn{7}{|c|}{ Mean square } \\
\hline & & Essential oil content [\%] & Menthol & Menthone & $\alpha$-Terpinene & Pulegone & Menthyl acetate & Menthofuran \\
\hline Rep.(block) & 2 & 0.004 & 0.217 & 0.147 & 0.014 & 0.0034 & 0.899 & 241.42 \\
\hline Treatment & 9 & $0.881^{\star *}$ & $7.035^{\star *}$ & $2.910^{* *}$ & $0.143^{* *}$ & $1.289^{\star *}$ & $1.130^{*}$ & $2.180^{* *}$ \\
\hline Error & 18 & 0.073 & 0.586 & 0.242 & 0.0091 & 0.298 & 0.453 & 0.181 \\
\hline CV (\%) & & 13.15 & 1.93 & 3.60 & 1.20 & 13.38 & 16.23 & 4.33 \\
\hline
\end{tabular}

$\star_{, * *}-\mathrm{ns}$ shows significant in $5 \%, 1 \%$, and insignificant, respectively 
Table 10

Mean comparisons for the effects of biostimulants formulations on growth parameters in field conditions

\begin{tabular}{lccc}
\hline Treatment $^{*}$ & Leaves dry weight per plant $[\mathrm{g}]$ & Stems dry weight per plant [g] & Shoot dry weight per plant [g] \\
\hline 1 & $2.63 \pm 0.78$ & $4.14 \pm 1.25$ & $6.86 \pm 1.10$ \\
\hline 2 & $4.53 \pm 0.73$ & $7.01 \pm 0.65$ & $11.63 \pm 1.32$ \\
\hline 3 & $3.52 \pm 0.45$ & $3.77 \pm 0.33$ & $7.41 \pm 0.64$ \\
\hline 5 & $4.42 \pm 1.31$ & $8.70 \pm 1.04$ & $13.22 \pm 2.33$ \\
\hline 6 & $5.18 \pm 1.11$ & $9.10 \pm 1.77$ & $14.36 \pm 2.89$ \\
\hline 7 & $5.33 \pm 0.49$ & $11.17 \pm 2.69$ & $16.58 \pm 2.28$ \\
\hline 8 & $4.28 \pm 1.19$ & $9.27 \pm 1.20$ & $13.65 \pm 2.36$ \\
\hline 9 & $3.02 \pm 0.65$ & $5.52 \pm 1.45$ & $8.63 \pm 2.08$ \\
\hline 10 & $3.66 \pm 0.80$ & $6.27 \pm 0.60$ & $10.01 \pm 0.35$ \\
\hline$* 1: C 0 n t r$ & $3.36 \pm 0.63$ & $5.62 \pm 1.35$ & $9.02 \pm 1.98$ \\
\hline
\end{tabular}

${ }^{*} 1$ : Control treatment (distilled water),

2: $400 \mathrm{mg} / \mathrm{l} \mathrm{CA}$

3: $400 \mathrm{mg} / \mathrm{l} \mathrm{HA}$

4: $800 \mathrm{mg} / \mathrm{l} \mathrm{HA}$

5: $200 \mathrm{mg} / \mathrm{l} \mathrm{CH}+400 \mathrm{mg} / \mathrm{l} \mathrm{CA}$

6: $400 \mathrm{mg} / \mathrm{l} \mathrm{CH}+400 \mathrm{mg} / \mathrm{l} \mathrm{CA}$

7: $200 \mathrm{mg} / \mathrm{l} \mathrm{CH}+400 \mathrm{mg} / \mathrm{l} \mathrm{HA}+400 \mathrm{mg} / \mathrm{l} \mathrm{CA}$

8: $200 \mathrm{mg} / \mathrm{l} \mathrm{CH}+800 \mathrm{mg} / \mathrm{l} \mathrm{HA}+400 \mathrm{mg} / \mathrm{l} \mathrm{CA}$

9: $400 \mathrm{mg} / \mathrm{l} \mathrm{CH}+400 \mathrm{mg} / \mathrm{l} \mathrm{HA}+400 \mathrm{mg} / \mathrm{l} \mathrm{CA}$

10: $400 \mathrm{mg} / \mathrm{l} \mathrm{CH}+800 \mathrm{mg} / \mathrm{l} \mathrm{HA}+400 \mathrm{mg} / \mathrm{l} \mathrm{CA}$

Table 11

Mean comparisons for the effects of biostimulants formulations on phytochemical parameters in field conditions

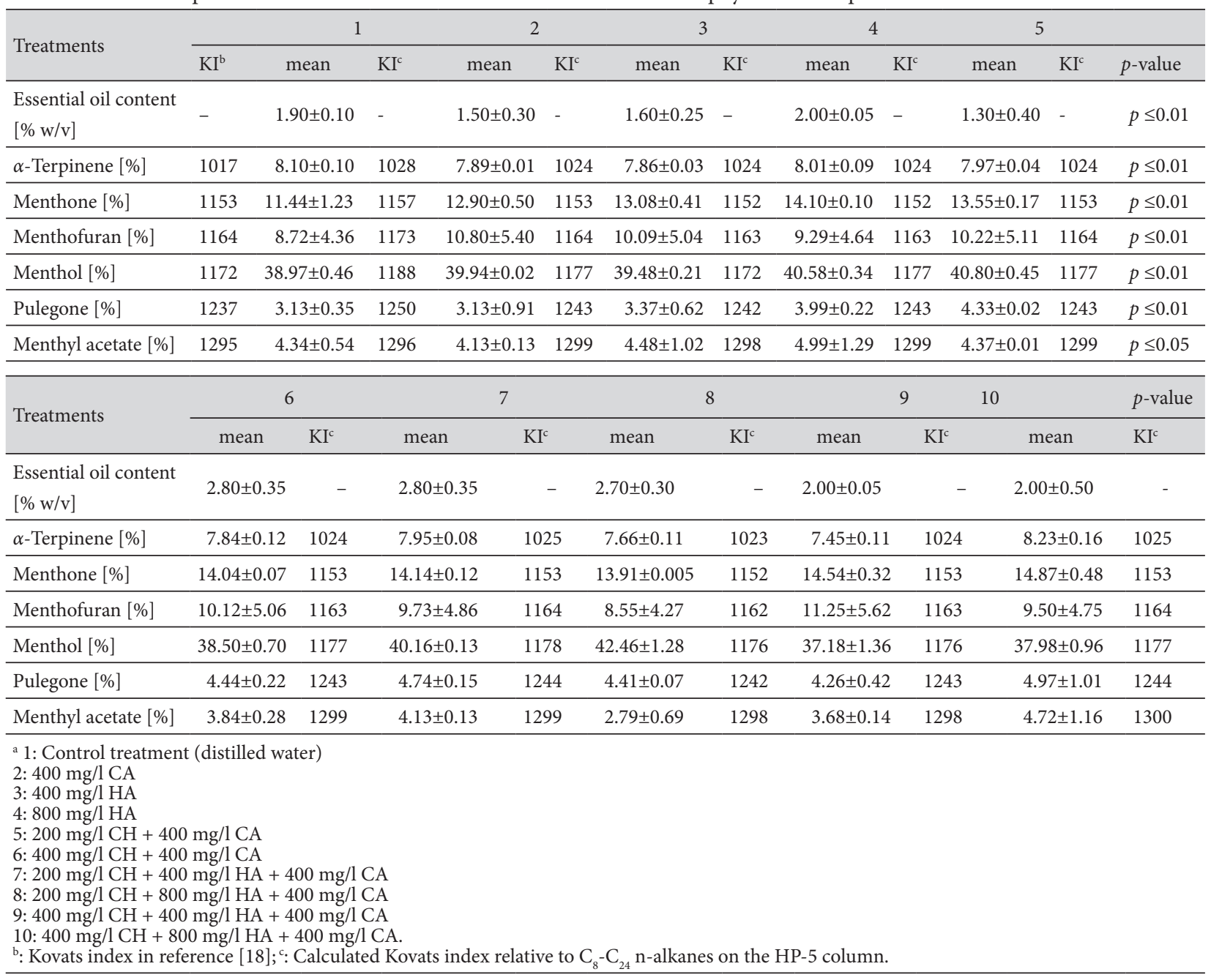


as compared to control. The HA stimulates the quantity and quality of yield as well as the growth of the plants by the effect on complex mechanisms involved in photosynthesis, cell respiration, biosynthesis of protein, enzyme activities, uptake of water and nutrient, improvement of soil structure and increase of microbial populations. The results of this research are in line with results of Salwa [22] experiment. $\mathrm{CH}$ is a linear $\beta$ - $(1,4)$-glucosamine polymer produced by deacetylation of chitin [23]. The penetration of $\mathrm{CH}$ into cells causes the inhibition of interference with the synthesis of mRNA and proteins [24]. The maximum amount of stems dry weight in the greenhouse was observed in $400 \mathrm{mg} / \mathrm{l}$ $\mathrm{CH}+800 \mathrm{mg} / \mathrm{l} \mathrm{HA}+400 \mathrm{mg} / \mathrm{l} \mathrm{CA}$ in comparison with control, while the treatment of $200 \mathrm{mg} / \mathrm{l} \mathrm{CH}+$ $400 \mathrm{mg} / \mathrm{l} \mathrm{CA}$ increased the yield of stems dry weight in the field. The $\mathrm{CH}$ as a biostimulant and bioprotectant has biological effects such as plant growth promotion, the direct growth inhibition of some pathogenic microorganisms, generally fungi and elicits induced resistance in plants against their pathogens [25]. The mode of action for HA in plant growth and development can be broadly divided into direct and indirect properties as it affects the membranes resulting in enhanced transport of nutritional elements, improved protein synthesis, enriched photosynthesis and solubilization of micronutrients [26]. These results are in line with Sheikha and AL-Malki [27]. They showed the enhancement of bean shoot and root length, fresh and dry weights of shoots, root and leaf area as well as the level of chlorophyll in leaves by application of $\mathrm{CH}$. According to results of Abu-Muriefah [28], foliar application of $200 \mathrm{mg} / \mathrm{l}$ $\mathrm{CH}$ in most cases resulted in a significant increase in plant growth parameters in common bean (Phaseolus vulgaris $\mathrm{L}$.) under normal or stressed conditions. In the greenhouse $400 \mathrm{mg} / \mathrm{l} \mathrm{CH}+800 \mathrm{mg} / \mathrm{l} \mathrm{HA}+$ $400 \mathrm{mg} / \mathrm{l} \mathrm{CA}$ caused the highest yield of shoots dry weight compared to control. The maximum increase in yield of shoots dry weight happened by application of $200 \mathrm{mg} / \mathrm{l} \mathrm{CH}+400 \mathrm{mg} / \mathrm{l} \mathrm{CA}$ in field. The valuable effects of $\mathrm{HA}$ and $\mathrm{CH}$ on plant growth and development may be attributed to the promoting effects on nutrients uptake and nutritional status especially nitrogen, potassium and phosphorous. According to Cho et al [29] results, $\mathrm{CH}$ treatments increased the total weight of sunflower plant, as compared to control. El-Nemr et al. [30] found that foliar application of HA with the highest concentration improved growth traits of Cucumber (Cucumis sativus L.) plants in comparison with control. The essential oil content was increased by two treatments of $400 \mathrm{mg} / \mathrm{l}$ $\mathrm{CH}+400 \mathrm{mg} / \mathrm{l} \mathrm{CA}$ and $200 \mathrm{mg} / \mathrm{l} \mathrm{CH}+400 \mathrm{mg} / \mathrm{l}$
$\mathrm{HA}+400 \mathrm{mg} / \mathrm{l} \mathrm{CA}$ in comparison with control treatment in filed, while in greenhouse the highest yield was occurred by $200 \mathrm{mg} / \mathrm{l} \mathrm{CH}+800 \mathrm{mg} / \mathrm{l} \mathrm{HA}+$ $400 \mathrm{mg} / \mathrm{l} \mathrm{CA}$ compared to control. HA has the positive effect on cell membrane functions by promoting nutrient uptake, respiration, biosynthesis of nucleic acid, ion absorption and enzyme activity as they are hormone-like substances [31]. According to results of Said-Al Ahl et al. [32], application of HA and indole acetic acid improved the essential oil content of dill (Anethum graveolens L.) plants in the field. These results are in line with those of Radmanesh et al. [33] on Satureja hortensis L. They reported that application of CA at 6 and $8 \mathrm{mM}$ increased the content of essential oil to the highest level. Loschke et al. [34] reported that $\mathrm{CH}$ causes the expression of a variety of genes involved in the plant defense response that results in increased synthesis of plant secondary metabolites. The essential oil component of menthol showed the highest yield with the treatment of $200 \mathrm{mg} / \mathrm{l} \mathrm{CH}+800 \mathrm{mg} / \mathrm{l} \mathrm{HA}+400 \mathrm{mg} / \mathrm{l} \mathrm{CA}$ compared to control in the field. In greenhouse the treatment of $400 \mathrm{mg} / \mathrm{l} \mathrm{CH}+400 \mathrm{mg} / \mathrm{l} \mathrm{HA}+400 \mathrm{mg} / \mathrm{l}$ CA increased in comparison with control treatment. According to results of El-Gohary et al. [35], application of HA treatments increased the component of menthol in peppermint plants. $\mathrm{CH}$ was found to enhance secondary metabolite production in cell suspensions and calli of various species [36]. Other essential oil components improved by application of biostimulants in field and greenhouse. These results are in agreement with results of Bagheri et al. [37] on Mentha spicata L. and Naeem et al. [38] on M. arvensis $\mathrm{L}$.

This study indicated that the content and components of essential oil in $M$. piperita L. were significantly changed by the environmental conditions. The essential oil content in field conditions was higher than in greenhouse conditions, meanwhile, the total amount of menthol and menthone in the greenhouse was greater than in field conditions. This is due to cool night temperatures in greenhouse that it can accelerate the conversion to menthone [6]. However, these results were consistent with results of Morales et al. [4] which stated essential oil content of Ocimum basilicum L. was significantly higher in the field than in the greenhouse.

\section{CONCLUSIONS}

The results of this study showed that growth and phytochemical responses of $M$. piperita $L$. to various biostimulants and their concentrations were 
different in the greenhouse and filed conditions. In general, the content of essential oil in leaves of M. piperita L. in the field conditions was significantly higher than that in the greenhouse. Although the menthol content in greenhouse and field was approximately similar, the menthone content in the greenhouse was higher than that in field conditions under different biostimulants treatments. The reason for different results by application of various biostimulants in greenhouse and field is the difference between the climates of both.

\section{ACKNOWLEDGEMENT}

The research was funded by Iranian Academic Center for Education, Culture \& Research (ACECR)-Institute of Medicinal Plants.

Conflict of interest: Authors declare no conflict of interest.

\section{REFERENCES}

1. Sustrikova A, Šalamon I. Essential oil of peppermint (Mentha piperita L.) from fields in Eastern Slovakia. Hort. Sci. (Prague), 2004; 31(1):31-36.

2. Turner GW, Gershenzon J, Croteau RB. Distribution of peltate glandular trichomes on developing leaves of peppermint. Plant Physiol. 2000; 124 (2):655-664.

3. Fletcher TS, Laima SK. Environmental factors affecting the accumulation of rosmarinic acid in spearmint (Mentha spicata L.) and peppermint (Mentha piperita L.). The Open Agric J. 2010; 4: 10-16. doi: http://dx.doi. org/10.2174/1874331501004010010

4. Aflatuni A. The yield and essential oil content of mint (Mentha ssp.) in northern of Trobothnia. Academic Dissertation, Faculty of Science, University of Oulu, Finland 2005.

5. McKay DL, Blumberg JB. A review of the bioactivity and potential health benefits of peppermint tea (Mentha piperita L.). Phytother Res 2006; 20 (8):619-633. doi: http://dx.doi. org/10.1002/ptr.1936
6. Morales MR, Simon JE, Charles DJ. Comparison of essential oil content and composition between field and greenhouse grown genotypes of methyl cinnanmate basil (Ocimum basilicum L.). J Herbs Spices Med Plants 2015; 1(4):25-30. doi: http://dx.doi.org/10.1300/J044v01n04_05

7. Gulluce M, Sahin F, Sokmen M, Ozer H, Daferara D, Sokmen A, et al. Antimicrobial and antioxidant properties of the essential oils and methanol extract from Mentha longifolia L. ssp. Longifolia. Food Chem 2007; 104(4):1449-1456.

8. Rafiee H, NaghdiBadi H, Mehrafarin A, Qaderi A, Zarinpanjeh N, Sekara A, et al. Application of plant biostimulants as new approach to improve the biological responses of medicinal plants. A critical review. J Med Plants 2016; 15(59):6-39.

9. New N, Chandrkrachang S, Stevens WF. Application of chitosan in Myanmar's agriculture sector, in: Proceedings of the Sixth Asia Pacific Chitin and Chitosan Symposium, May 23-26, The National University of Singapore, Singapore 2004.

10. Ya-jing G, Hu J, Wang X, Shao C. Seed priming with chitosan improves maize germination and seedling growth in relation to physiological changes under low temperature stress, J Zhejiang Univ Sci B 2009; 10(6):427-433. doi: http:// dx.doi.org/10.1631/jzus.B0820373

11. Farouk S, Ghoneem KM, Ali Abeer A. Induction and expression of systematic resistance to downy mildew disease in cucumber plant by elicitors, Egypt J Phytopathol 2008; 1(2):95-111.

12. Farouk S, Mosa AA, Taha AA, Ibrahim Heba M, EL-Gahmery AM. Protective effect of humic acid and chitosan on radish (Raphanus sativus $\mathrm{L}$. var. sativus) plants subjected to cadmium stress. J Stress Physiol Biochem 2011; 7(2):99-116.

13. Ghoname AA, EL-Nemr MA, Abdel-Mawgoud AMR, El-Tohamy WA. Enhancement of sweet pepper crop growth and production by application of biological, organic and nutritional solutions, Res J Agric Biol Sci 2010; 6(7):349-355.

14. Bittelli M, Flury M, Campbell GS, Nichols EJ. Reduction of transpiration through foliar application of chitosan, Agric for Meteorol 2001; 
107(3):167-175. doi: http://dx.doi.org/10.1016/ S0168-1923(00)00242-2

15. Abdel-Mawgoud AMR, Tantawy AS, El-Nemr MA, Sassine YN. Growth and yield responses of strawberry plants to chitosan application, Eur J Sci Res 2010; 39(1):161-168.

16. Pamela C, Louise N, Joseph WK. Agricultural uses of plant biostimulants. Plant Soil 2014. doi: http://dx.doi.org/10.1007/s11104-014-2131-8

17. Soccol CR, Vandenberghe LPS, Rodrigues C, Pandey A. New perspectives for citric acid production and application, Food Technol Biotechnol 2006; 44(2):141-149.

18. Lehninger AL. CursoBreve de Bioquimica, Ediciones Omega, Barcelona 1979:214-223.

19. British Pharmacopoeia, HMSO, London 1988; 2: A137 - A:138.

20. Adams RP. Identification of essential oil components by gas chromatography/quadrupole mass spectroscopy, Allured Publishing. Carol Stream, IL, USA 2001; pp: 469.

21. Swigar AA, Silverstein RM. Monoterpenes, Aldrich Chemical, Milwaukee 1981.

22. Salwa MA. The influence of biostimulants on the growth and on the biochemical composition of Vicia fabia CV. Giza 3 beans. Roma Biotech Lett 2013; 18 (2):8061-8068.

23. Mahdavi B, Rahimi A. Seed priming with chitosan improves the germination and growth performance of ajowan (Carum copticum) under salt stress. Eurasia J Biosci 2013; 7:69-76. doi: http://dx.doi.org/10.5053/ejobios.2013.7.0.9

24. Abdel-Kader MM, El-Moungy NS, Aly MDE, Lashin SM. Integration of biological and fungicidal alternatives for controlling foliar diseases of vegetables under greenhouse conditions. Int J Agric For 2012; 2(2): 38-48. doi: http://dx.doi. org/10.5923/j.ijaf.20120202.07

25. Bautista-Baños S, Hernández-Lauzardo AN, Velázquez-del Valle MG, Hernández-López M, AitBarka E, Bosquez-Molina E, et al. Chitosan as a potential natural compound to control pre and postharvest diseases of horticultural com- modities. Crop Protect 2006; 25 (2):108-118. doi: http://dx.doi.org/10.1016/j.cropro.2005.03.010

26. Mac Carthy P, Clapp CE, Malcdm RL, Bloom PP. Humic substances in soil and crop sciences. Soil Sci Soc Am Madison 1999. doi: http://dx.doi. org/10.2136/1990.humicsubstances.frontmatter

27. Sheikha SA, Al-Malki FM. Growth and chlorophyll responses of bean plants to chitosan applications. Eur J Sci Res 2011; 50(1):124-134.

28. Abu-Muriefah S. Effect of chitosan on common bean (Phaseolus vulgaris L.) plants grown under water stress conditions, Int Res J Agric Sci Soil Sci 2013; 3(6):192-199.

29. Cho MH, No HK, Prinyawiwatkul W. Chitosan treatments affect growth and selected quality of sunflower sprouts. J Food Sci 2008; 73 (1):570577. doi: http://dx.doi.org/ 10.1111/j.17503841.2007.00607.x

30. El-Nemr MA, El-Desuki M, El-Bassiony AM, Fawzy ZF. Response of growth and yield of cucumber plants (Cucumis sativus L.) to different foliar application of humic acid and bio-stimulators. Aust J Basic Appl Sci 2012; 6(3):630-637.

31. Yang CM, Wang MH, Lu YF, Chang IF, Chou $\mathrm{CH}$. Humic substances affect the activity of chlorophyllase. J Chem Ecol 2004; 30(5):10571065.

32. Said-Al Ahl HAH, El Gendy AG, Omer EA. Humic acid and indole acetic acid affect yield and essential oil of dill grown under two different locations in Egypt. J Pharm Sci Res 2016; 8(7):504-606.

33. Radmanesh E, NaghdiBadi H, Hadavi E, Mehrafarin A. Shoot growth, Gamma-terpinene and essential oil content of Satureja hortensis L. in response to foliar application of $\mathrm{FeSO}_{4}$ and citric acid. J Med Plants 2015; 14 (53):45-57. doi: http://dx.doi.org/10.1016/0048-4059(83)900437

34. Loschke DC, Hadwiger LA, Wagoner W. Comparison of mRNA populations coding for phenylalanine ammonialyase and other peptides from pea tissue treated with biotic and abiotic phytoalexin inducers. Physiol Plant Pathol 1983; 23(1):163-173.

35. El-Gohary AE, El-Sherbeny SE, Ghazal GMEM, 
Khalid KA, Hussein MS. Evaluation of essential oil and monoterpenes of peppermint (Mentha piperita L.) under humic acid with foliar nutrition. J Mater Environ Sci 2014; 5(6):1885-1890.

36. Asghari-zakaria R, Maleki-zanjani B, Sedghi E. Effect of in vitro chitosan application on growth and minituber yield of Solanum tuberosum L. Plant Soil Environ 2009; 55(6):252-256.

37. Bagheri S, Davazdah emami S, Minooyi Moghadam J. Variation in growth characteristics, nu- trient uptake, and essential oil content in three mycorrhizal genotype of Mentha spicata L. Int J Sci Res Knowl 2015; 3 (3): 067-076. doi: http:// dx.doi.org/10.12983/ijsrk-2015-p0067-0076

38. Naeem M, Idrees M, Aftab T, Khan Moinuddin MMA, Varshney L. Depolymerised carrageenan enhances physiological activities and menthol production in Mentha arvensis L. Carbohydr Polym 2012; 87 (2): 1211-1218. doi: http:// dx.doi.org/10.1016/j.carbpol.2011.09.002

\title{
Odpowiedź biochemiczna i wzrost Mentha piperita po dolistnym podaniu biostymulatorów w warunkach szklarniowych i polowych
}

\author{
MEISAM POURHADI ${ }^{1}$, HASSANALI NAGHDI BADI ${ }^{2 *}$, ALI MEHRAFARIN ${ }^{2}$, HESHMAT OMIDI $^{3}$, \\ REZA HAJIAGHAEE ${ }^{2}$
}

${ }^{1}$ Department of Horticulture

Science and Research Branch

Islamic Azad University

Tehran, Iran

${ }^{2}$ Medicinal Plants Research Center

Institute of Medicinal Plants, ACECR

Karaj, Iran

${ }^{3}$ Agricultural College and Medicinal Plants Research Centre

Shahad University

Tehran, Iran

*autor, do którego należy kierować korespondencję: tel.: +98 2634764010 9, faks: +98 2634764021 ,

e-mail: naghdibadi@yahoo.com; h.naghdi@imp.ac.ir

\section{Streszczenie}

Wstęp: Produkty biostymulujące mają właściwości podnoszące jakość i plon roślin leczniczych.

Cel: Porównanie efektów spryskiwania biosymulatorami liści mięty pieprzowej.

Metody: Badanie przeprowadzono w 2015 r. metodą wybranych losowo kompletnych bloków w trzech powtórzeniach. 
Wyniki: W warunkach polowych najwyższy plon suchej masy łodyg i liści otrzymano przy zastosowaniu 400 mg/l chitosanu $(\mathrm{CH})+400 \mathrm{mg} / \mathrm{l}$ kwasu cytrynowego (CA), zawartość olejku eterycznego przy użyciu 200 mg/l chitosanu + $400 \mathrm{mg} / \mathrm{l} \mathrm{kwasu} \mathrm{humusowego} \mathrm{(HA)} \mathrm{+} 400$ mg/l kwasu cytrynowego oraz zawartość mentolu przy zastosowaniu $200 \mathrm{mg} / \mathrm{l}$ chitosanu + $800 \mathrm{mg} / \mathrm{l} \mathrm{kwasu} \mathrm{humusowego}+400 \mathrm{mg} / \mathrm{l} \mathrm{kwasu} \mathrm{cytrynowego.}$ W warunkach szklarniowych najlepsze wyniki powyższych parametrów uzyskano, stosując odpowiednio $400 \mathrm{mg} / \mathrm{l} \mathrm{chitosanu}+800 \mathrm{mg} / \mathrm{l} \mathrm{kwasu} \mathrm{humusowego} \mathrm{+} 400 \mathrm{mg} / \mathrm{l} \mathrm{kwasu} \mathrm{cytrynowego,} 800 \mathrm{mg} / \mathrm{l} \mathrm{kwasu} \mathrm{humu-}$ sowego oraz $400 \mathrm{mg} / \mathrm{l}$ chitosanu $+400 \mathrm{mg} / \mathrm{l} \mathrm{kwasu} \mathrm{humusowego}+400 \mathrm{mg} / \mathrm{l} \mathrm{kwasu} \mathrm{cytrynowego.}$

Wniosek: Stosowanie dolistne efektywnych biostymulantów może podnieść jakość i plon mięty pieprzowej.

Słowa kluczowe: Mentha piperita L., chitosan, kwas cytrynowy, kwas humusowy, olejek eteryczny, mentol 